\section{Carlos Heitor Cony e as crônicas contra - golpe militar de 1964 no jornal Correio da Manhã}

\author{
Maurício Guilherme SILVA JÚNIOR ${ }^{1}$
}

Resumo: No referido artigo, busca-se investigar os "modos" como, por meio da crônica diária, o escritor e jornalista Carlos Heitor Cony construiu um discurso singular de resistência à "revolução dos caranguejos", segundo definição do próprio autor. Logo após a instauração do regime militar no País, o autor, então funcionário do jornal Correio da Manhã, será uma das poucas vozes a se rebelar publicamente - com o auxílio dos recursos e possibilidades da arte do "cronismo" - contra o governo autoritário.

Palavras-chave: Crônica; Jornalismo; Correio da Manhã; Carlos Heitor Cony; Golpe Militar de 1964.

Resumen: En ese artículo, tratamos de investigar los "modos" como, a través de la crónica diaria, el escritor y periodista Carlos Heitor Cony construido un discurso natural de resistencia a la "Revolución de los Cangrejos", según lo definido por el autor. Poco después de la instauración del régimen militar en Brasil, el autor, entonces empleado del periódico Correio da Manha, se convierte en una de las pocas voces capaces de rebelarse públicamente - con la ayuda de los recursos y posibilidades del arte de "cronismo" - contra el gobierno autoritario.

Palabras clave: Crónica; Periodismo; Correio da Manhã; Carlos Heitor Cony; Golpe Militar de 1964.

\section{Introdução}

Em março de 1964, desabrochava no Brasil o movimento militar definido, pelo escritor e jornalista carioca Carlos Heitor Cony, como "a revolução dos caranguejos" (CONY, 2004) - irônica definição para o

1 Graduado em Jornalismo (1999) pela UFMG, mestre e doutor em Estudos Literários (UFMG - 2004/2012), é professor do curso de jornalismo do Centro Universitário de Belo Horizonte (UniBH). Seu e-mail de contato é mgsi@uol.com.br. movimento militar que, a seu ver, "caminhava para trás". Desde os primeiros instantes do golpe que levaria a nação a vinte e um anos de autoritarismo, repressão e censura, assim como ao esfacelamento dos princípios de cidadania $^{2}$ fundamentais à ordem social, um irrequieto Cony, então repórter e cronista do jornal Correio da $\mathrm{Ma}$ $n h a \tilde{a}$, transforma-se na voz, ferina por excelência, capaz de estimular diariamente, em milhares de leitores, o "exercício vital de oxigenação" (VERISSIMO, 2004, p. 9).

Autor, até então, de seis romances e um livro de crônicas, o escritor passaria a exercitar a "arte" de problematizar os rumos da "nau" política, social e econômica do País em meio ao inusitado e tormentoso mar que se afigurava. Já no dia 2 de abril daquele fatídico ano, em sua coluna fixa no jornal, o cronista publica "Da salvação da pátria", texto em que revela perplexidade diante da "arcaica novidade" política: "Posto em sossego por uma cirurgia e suas complicações, eis que o sossego subitamente se transforma em desassossego: minha filha surge esbaforida dizendo que há revolução na rua" (CONY, 2004, p. 11).

O inesperado burburinho da "revolução" faria com que, a partir dali, um surpreso Cony - que, digase de passagem, não se filiara a grupos políticos ou a propostas categoricamente ideológicas - passasse a descrever e questionar, por meio da palavra, as muitas incongruências do regime militar instaurado no Brasil. Trata-se, aliás, do golpe de estado cujos alicerces remontam, na visão do autor, à "mesma divisão esquemática que cindira a Convenção Francesa, quase dois séculos antes" (CONY, 2004, p. 7).

Diante da nação sitiada, os olhos do cronista anseiam por denunciar não só a repressão dos militares - e sua miríade de ordenamentos -, mas também os efeitos da máquina capitalista sobre o "ser" e o "fazer" dos cidadãos da nação periférica. Os textos de Cony no Correio da Manhã servirão de sátira ao país regido por "inteligências" e princípios ideológicos diversos, do autoritarismo que se avizinha, a partir da "revolução dos caranguejos", às práticas dos antigos baluartes do interesse nacional: a classe média e seu permanente desejo de consumo; a intelligentzia, superficial e maniqueísticamente dividida entre "esquerda", "direita" ou "centro"; e a alta burguesia, ansiosa por integrar-se ao vasto capital mundial.

Em sua coluna, intitulada $D a$ arte de falar mal e publicada no mesmo Correio da Manhã, Cony acostumarase a abordar temáticas aparentemente banais, do destino

2 Termo aqui compreendido como o tripé social formado por direitos civis, políticos e sociais (CARVALHO, 2003). 
da ossada de Dana de Teffé ${ }^{3}$ às divertidas peripécias de um certo "escritor sem livros", a vagar pelo Rio de Janeiro em busca de "público e amor" (CONY, 1963, p. 62). O próprio título da seção é capaz de revelar o teor provocativo dos textos, muitos dos quais seriam reunidos, pelo autor, em livro homônimo, lançado nos idos de 1963.

Mesmo diante de acontecimentos como a renúncia de Jânio Quadros ou as celeumas em torno do governo João Goulart, o cronista revela-se esquivo, soturno, silente, a ponto de ocupar, na vida cultural brasileira, uma espécie de "não-lugar" - pois que distante dos "assuntos da nação", sempre recheados de articulações políticas, partidárias e/ou ideológicas. À época, aliás, muitos seriam aqueles a taxá-lo de alienado, justamente por não se posicionar quanto aos diversos problemas do País.

Após a instauração do golpe militar, contudo, transmutam-se os sentidos do conceito de "não-lugar", que passa a designar, tão somente, a pouca disposição de Cony em estabelecer vínculos dogmáticos, passíveis de lhe coibir, direta ou indiretamente, o livre exercício do pensamento. Ressalte-se, porém, que, mesmo no período anterior à eclosão do golpe militar, ao recorrer a temáticas visivelmente comezinhas, o cronista pretendia, a seu modo, estimular a discussão em torno de uma série de questões comportamentais e, na essência, também sociopolíticas. Conforme destaca Sandroni (2003, p. 88), “em cada palavra que escrevia [na coluna Da arte de falar mal], sobre os ciclistas búlgaros ou sobre a morte do seu avô, [Cony] falava sobre a condição humana".

Neste sentido, para além da louvação estética do cotidiano, o autor entregava-se à inquirição do(s) modo(s) de vida dos indivíduos no interior de sociedades periféricas, marcadas pela rotina de violência, desemprego e desigualdade. Em seus textos, perseguia, assim, a moldura fundamental ${ }^{4}$ - expressa em assuntos leves, corriqueiros, próximos ao leitor -, onde indagações filosóficas e sociopolíticas pudessem melhor se conformar.

A partir de 1964, tais "molduras" são obrigadas a se modificar, pois que a violência a ser combatida revela-se escancarada, e os textos do cronista - apesar de sua recorrência à ironia, à metáfora e à analogia - tornam-se

3 Cidadã tcheca, Dana Fitscherova casa-se, na década de 1950, com o embaixador brasileiro Manuel de Teffé von Hoonholtz, descendente do Barão de Teffé e do Conde von Hoonholtz. Suposta vítima de assassinato, Dana desaparece em 1961. Seus restos mortais jamais seriam encontrados.

4 Referência a termo de Goffman, citado por Luiz Costa Lima (2006), que, ao discutir as distinções entre os discursos da história, da ficção e da literatura, comenta as diversas formas de acepção verbal da realidade. A noção de moldura é construída para explicar os diversos "estilos cognitivos" impostos, no cotidiano, às relações entre os indivíduos. mais informativos, contestatórios e articulados aos acontecimentos (sociopolíticos) do carrilhão da história. Seu olhar, antes afeito à aparente simplicidade da vida, passaria a observar os generais no poder e as reações sociais às iniciativas dos mandantes.

De 2 de abril a 9 de junho de 1964, o autor escreveria as 37 crônicas de resistência ao regime autoritário que, naquele mesmo ano, seriam reunidas e publicadas ${ }^{5}$ no livro $O$ ato e o fato. Em tais narrativas, o cronista não apenas problematiza as iniciativas dos militares no poder, mas também, e principalmente, elabora seu "testemunho" acerca dos movimentos em meio à nação sitiada.

Importante frisar que o termo "testemunho" é aqui compreendido a partir da conceituação de Márcio Seligmann-Silva (2003, p. 8), que o compreende

tanto no sentido jurídico e de testemunho histórico - ao qual o testimonio tradicionalmente se remete nos estudos literários - como também no sentido de "sobreviver", de ter-se passado por um evento-limite, radical, passagem essa que foi também um 'atravessar' a 'morte', que problematiza a relação entre a linguagem e o "real" (Seligmann-Silva, 2003, p. 8).

Justamente como forma de investigar os testemunhos do cronista Carlos Heitor Cony, referentes ao golpe de 1964 - e suas reverberações políticas, sociais, culturais, artísticas, econômicas etc. -, buscou-se, neste artigo, a investigação das estratégias narrativas do autor, por meio da análise de conteúdo ${ }^{6}$ de "crônicas de resistência” publicadas no Correio da Manhã e, posteriormente, reunidas em $O$ ato e o fato (1964).

\section{Um cronista diante dos rifles}

Se muitas são as narrativas esculpidas pela memória, tantas outras desenvolvem-se no calor da hora, ainda sob o pulsar dos acontecimentos. Naquele $1^{\circ}$ de abril de 1964, como "testemunha ocular da história" , o

5 A noite de autógrafos para lançamento do livro, realizada em julho de 1964, acabaria por se transformar na primeira manifestação civil espontânea após o golpe militar.

6 Trata-se da técnica de investigação interessada na descrição (objetiva, sistemática e/ou quantitativa) do conteúdo manifesto no "processo comunicativo" - o que, no presente artigo, diz respeito aos diálogos e significados estimulados pelas crônicas de Carlos Heitor Cony. 7 Rápida homenagem ao Repórter Esso, programa jornalístico que, de 1941 a 1970 - primeiramente na Rádio Nacional; depois, na TV Tupi -, arvorava-se porta-voz dos acontecimentos do mundo. 
cronista percebe que não lhe restarão alternativas, senão responder a tudo no exato instante em que, diante de seus olhos, lateja a vida... E se define a morte. Nas ruas do Rio de Janeiro, ao assistir à movimentação dos tanques - e dos coturnos e dos rifles e de toda a ânsia verde-oliva pelo fim do etéreo "perigo vermelho" -, Carlos Heitor Cony observa a "vitória dos 'rebeldes" (CONY, 1964; 2010), mas não a compreende de todo.

Afinal, de que forma imaginar tamanha rebeldia da parte de homens como Eugênio Gudin e Augusto Frederico Schmidt, para não falar do almirante Pena Bôto e do Marechal Gaspar Dutra? O que pensar e dizer, então, das mulheres "de terço na mão, chorando porque a 'revolução' havia sido ganha” (CONY, 1964; 2004) e permanecer impávido diante dos tantos "rosários brandidos pelas pias senhoras"? De que modo, por fim, compreender a frase "a revolução foi ganha por nós", posto que a própria ideia de "revolução", em tal conjuntura, revelava-se, na visão do autor, inconcebível e incompreensível?

Pois não é que, do pasmo ante os fatos, surgiriam os atos? Justamente das incongruências do tempo nascem as primeiras impressões do cronista acerca do nebuloso golpe militar, então publicadas pelo Correio da Manhã já no dia seguinte às cenas presenciadas no Forte de Copacabana. Trata-se, como se sabe, do primeiro de uma série de petardos verbais com destinatário preciso (e de diversa patente): marechais, coronéis e generais responsáveis pela inacreditável "quartelada" que parecia ter paralisado o Brasil (CONY, 1964; 2004).

De sua coluna no jornal Correio da Manhã - veículo que, inicialmente, defenderia a atitude dos militares, como reação necessária aos "desmandos" do presidente João Goulart -, Cony passaria a desfiar sua "ira”. E que ninguém se assuste com o uso de tal termo, posto que a intensidade do substantivo mostra-se condizente ao teor e ao tom das narrativas de Cony, as quais, publicadas a cada dois dias, eram ansiosamente aguardadas pelos leitores como do engabelar todo o mundo" (VERISSIMO, 2004, p. 8).

Já na orelha da edição original de $O$ ato e o fato, Hermano Alves atenta para a ferocidade das crônicas reunidas no livro. O crítico recorre, exatamente, ao substantivo aqui destacado como elucidativo da reação do cronista perante a "quartelada": "Um acesso de ira de Carlos Heitor Cony trouxe, ao jornalismo brasileiro, algumas de suas melhores páginas panfletárias. E foi uma ira santa a que moveu êsse ex-seminarista que, inda hoje, em cada uma de suas obras de ficção, continua em busca da fé" (ALVES, 1964, Orelha).

No entanto, para além da procura do cronista pela fé, ressalte-se, como bem comentado por Verissimo (2004), a representatividade coletiva das crônicas de Cony no aludido período. Ao recolher "fragmentos da vida" em meio à nação inesperadamente sitiada pelo autoritarismo, o autor - sem que o previsse - transforma-se numa espécie de porta-voz do pensamento e do sentimento de muitos. O próprio Hermano Alves comenta que

todo mundo reconhecerá que, nesses arLiberdade" transformou-se, no Rio, tigos, refletiu-se a consciência da nação brasileira, ferida em suas tradições e golpeada em suas instituições. Cony falou por todos, na hora em que muitos não podiam dizer palavra e em que tantos outros preferiram silenciar. Ninguém roubará de Cony essa glória, que nós nos orgulhamos de proclamar (ALVES, 1964, Orelha).

Afora Cony, nas semanas subsequentes à "revolução" verde-oliva, parte significativa da mídia nacional inclusive o depois combativo Correio da Manhã - saudaria o movimento como "recurso" necessário ao ordenamento da Federação. Que o diga a edição especial da revista Manchete, publicada em abril de 1964, cuja capa estamparia um sorridente Carlos Lacerda, então governador do ex-estado da Guanabara, extremamente feliz com a instauração, pelas Forças Armadas, do "processo moralizador da nação". Já na primeira reportagem da série, sob o título "Deus, família e liberdade", a publicação consagra a hoje histórica passeata pela "ordem civilizatória":

A "Marcha da Família com Deus pela

63

uma espécie de cidadela intelectual em que também resistíamos - mesmo que a resistência consistisse em apenas dizer "É isso mesmo!", ou "Dá-lhe, Cony!", a cada duas frases lidas. "Leu o Cony hoje?" passou a ser a senha de uma conspiração tácita de inconformados passivos, cujo lema silencioso seria "Pelo menos eles não estão conseguin- 
numa verdadeira homenagem às fôrças armadas, ao ser anunciada a presença do General Olímpio Mourão Filho, de destacada atuação nos recentes acontecimentos. Também compareceram os Marechais Dutra, Magessi, Mendes de Morais e Segadas Viana. A incalculável multidão concentrou-se ao lado da Candelária, com imagens, terços, bandeiras e cartazes anticomunistas. E dali deslocou-se para a Esplanada do Castelo, onde renovou a impressionante demonstração de fé católica e de confiança no Brasil (MANCHETE, 1964, p. 4).

A partir do golpe militar, e diante de tais manifestações sociais de anticomunismo, "fé católica" e “confiança no Brasil”, Cony não conseguira se calar. Daí os textos solitários do cronista no Correio da Manhã, os quais, curiosamente, surpreenderão centenas de leitores, críticos especializados e partidários da esquerda, que, até então, insistiam em ressaltar, como inatos à escrita do autor, apenas o deboche, a rudeza de termos e, com ênfase, a alienação política. Para Ruy Castro (2009), o escritor,

já considerado "negativista" e "rude" por seus romances, ficou famoso como o cronista cético e debochado de "Da arte de falar mal", a coluna que publicava três vezes por semana no Correio.

Pior que cético e debochado: um alienado político, pelo menos aos olhos das esquerdas pré-1964, que exigiam definições. Elas não sabiam o que pensar de um sujeito tão hidrofobamente individualista numa época em que, com Jango Goulart na presidência, urgiam as mobilizações coletivas: o Brasil ia fazer as reformas, expulsar os americanos, instaurar a ditadura do proletariado, pintar os canecos.

Pois, em meio a essa balbúrdia, o cronista Cony só parecia se preocupar com ciclistas búlgaros, com o Grande e verdadeiro livro de São Cipriano e com um estranho apêndice do corpo chamado piloro. Pois, no dia $1^{\circ}$ de abril de 1964 , instaurado o golpe, todos - à direita e à esquerda - tiveram uma surpresa.
Cony, alérgico a política e ideologias, viu seus amigos sendo presos e perseguidos pelo novo regime e indignou-se.

Tornou-se de repente uma voz isolada e sonante da oposição (CASTRO, 2009, p. 116-117).

Editor da Civilização Brasileira e colega de Cony no Correio da Manhã, Ênio Silveira escreve, no bem elaborado prefácio da primeira versão de $O$ ato e o fato, o definitivo perfil do cronista que - a partir de sagaz observação do cenário político - resolvera enfrentar os "leões" e dizer, na contramaré do pensamento hegemônico, o que lhe vinha à mente. Na visão de Silveira (1964), muitos haviam imaginado revoltar-se contra os militares, mas "um jornalista do Correio, mais do que qualquer outro, se transformou no panfletário que a hora exigia e a Nação esperava para lavar a face e levantar a cabeça. Seu nome, hoje conhecido em todo o Brasil: Carlos Heitor Cony" (SILVEIRA, 1964, Prefácio).

Com seu "espírito propício ao uso público da razão" - e os olhos abertos às dinâmicas sociais -, Cony segue na contracorrente ao pensamento hegemônico, de modo a se tornar figura seminal à interpretação do ambiente sociopolítico no Brasil do pós-golpe. Neste turbulento cenário, para realmente desempenhar o "papel de aríete" capaz de forçar "as portas da masmorra ditatorial” (SILVEIRA, 1964, Prefácio), o autor recorre, uma vez mais, ao "território narrativo" onde se acostumara à "arte de falar mal": só mesmo a crônica seria capaz de garantir a agilidade e a exposição necessárias ao cumprimento dos objetivos de sua ira.

Afinal, no espaço plurissignificativo da crônica, o "eu narrativo" teria a possibilidade de, ao mesmo tempo, instaurar profícuos diálogos com o leitor; questionar atos, fatos e princípios - tanto dos vitoriosos quanto dos vencidos -; denunciar abusos de poder; realizar análises conjunturais; além de recorrer à analogia, à metáfora e à ironia, como forma de suportar e compreender as arbitrariedades de uma nação sitiada.

Como forma de discutir o ambiente sociopolítico brasileiro pós-golpe e, ao mesmo tempo, estimular a reflexão - e o espírito dissidente - em seu leitor, o autor recorre a três grandes estratégias narrativas, consciente e acuradamente desenvolvidas nas crônicas reunidas em $O$ ato e fato. Trata-se, em síntese, da tríade de recursos linguísticos, retóricos e temáticos responsáveis, nos textos de Cony, por uma série de efeitos, entre os quais: a construção - imagética e verbal - de um País particularís- 
simo, cujos indivíduos, atitudes e males são devidamente observados, dissecados e, por vezes, denunciados; a conclamação à dissidência - política, social, comportamental etc. -, único meio eficaz de resistência ao autoritarismo estabelecido; a degradação dos sujeitos - indivíduos e/ ou instituições - tidos por mentores da "quartelada" e, por fim, a "pintura" da falência dos homens modernos e seu "projeto falido".

Em seus textos de resistência ao golpe militar de 1964, portanto, Cony busca, em primeiro lugar, fortalecer as possibilidades de exposição do "eu narrativo", que, autônomo, direto, agressivo e panfletário, revigorase, crônica a crônica, ao apresentar suas próprias versões para os fatos do Brasil sitiado, assim como ao denunciar e perfilar os responsáveis pelo mal que se apossara do País. Neste cenário, o cronista também recorre a amplo volume de dados históricos e/ou jornalísticos - muitos dos quais, inéditos -, de modo a tornar credível o espaço narrativo da crônica como "fonte de informação". Há que se ressaltar, neste sentido, o estímulo, por parte do autor, em intensificar a relação entre o "eu narrativo" e o "carrilhão" da história.

Como segunda estratégia narrativa, o cronista investe na ampliação de seu diálogo com o leitor, por meio, principalmente, da conclamação à luta, expressa, inúmeras vezes, pelo uso da primeira pessoa do plural. No que se refere a tal "dialogismo", percebem-se, ainda, a recorrência a conversas diretas entre o autor e seus interlocutores, o uso de imagens e/ou descrições de cenas aparentemente capazes de "transportar" os leitores ao "terrível palco" dos acontecimentos e a repetição de termos e expressões capazes de estimular, no outro, o sentimento de identificação às causas propostas e/ou debatidas.

Por fim, como "terceira via" estratégica de ação, Cony aborda com frequência, direta ou indiretamente, temáticas relativas às condições de sub-humanidade, enfrentadas, após o golpe militar, por ampla parcela da população brasileira. Desse modo, o cronista pretende, uma vez mais, denunciar a progressiva falência da raça humana sobre a face da Terra.

\section{Das angústias do "eu” aos desígnios da história}

Em praticamente todas as crônicas reunidas em $O$ ato e o fato, revela-se, impetuosa, a tensão ${ }^{9}$ entre o mi-

8 http://www.carlosheitorcony.com.br/noticia.aspx?nNOT_Codigo $=84$.

9 Retome-se, neste momento, o significativo tratamento concedido ao termo por Bosi (2002), para quem subjaz, no vocábulo, certa proposta imanente de resistência. No campo da escrita, conforme já exposto, crouniverso do narrador - a ser aqui denominado "eu narrativo" - e a macrorrealidade da história. Em outros termos, destaque-se a frequente aparição, na escrita de Cony acerca do golpe militar, de situações em que o cotidiano do cronista entrelaça-se, de maneira quase simbiótica, aos acontecimentos do mundo.

Já no parágrafo inicial da crônica que abre o livro, explicita-se a confinante relação entre o "eu narrador" e as "circunstancialidades" do tempo histórico. Materializa-se, ali, e logo nos primeiros vestígios do diálogo cronista/leitor, a "revelação" em torno da unidade a ser conscientemente esculpida ao longo de toda a obra: trata-se da composição narrativa em cuja estrutura serão manipuladas, à forma de ingredientes, a sempre imprevista argamassa do mundo de fora e a experiência sensível do mundo de dentro - a "caverna da alma", segundo Santo Agostinho.

Em "Da salvação da pátria", relata o autor, em tom confessional: "Posto em sossego por uma cirurgia e suas complicações, eis que o sossego subitamente se transforma em desassossego: minha filha surge esbaforida dizendo que há revolução na rua" (CONY, 2010, p. 11). Já nas linhas iniciais do texto - que, ressalte-se, é cronologicamente representativo do primeiro "grito resistente" de Cony no Correio da Manhã - articulam-se, como numa teia, os muitos sentidos dos termos usados pelo cronista.

Em primeiro lugar, importante ressaltar a tensão, concebida pelo autor, entre as dinâmicas íntimas do "eu narrativo" (da doença à convalescença; do sossego ao desassossego) e as mobilizações do mundo de fora (da calmaria à revolução). Somem-se, a tal estratégia, os dois elementos responsáveis, no parágrafo, pela junção das instâncias de ordem pessoal e histórica: de um lado, o vocábulo "complicações", a unir "sujeitos" aparentemente distantes e a revelar que tanto o cronista quanto o País passam por mudanças de profunda dificuldade; de outro, a personagem da "filha", que, diante do leitor, cumprirá o papel de porta-voz "autorizada" das ruas - assim como de intérprete privilegiada, para o cronista, dos novos e inesperados acontecimentos.

As imagens da "revolução", descritas ao cronista por sua filha, dizem respeito ao momento em que tropas, procedentes de Minas Gerais, "apossavam-se" do Rio de Janeiro. Os instantes iniciais da aventura dos militares ${ }^{10}$, que chegavam à antiga capital federal com o intuito de pôr fim ao "perigo comunista" - protagonizado, no julgamento de parte significativa da população brasileira, trata-se da "tensão eu/ mundo", expressa segundo perspectiva crítica. 10 Trata-se das tropas militares comandadas pelo general Olímpio Mourão Filho.

65 
por João Goulart e suas reformas de base -, seriam assim descritos por Thomaz Skidmore (1988):

Foi ao amanhecer de $1^{\circ}$ de abril de 1964. $\mathrm{Na}$ véspera o presidente João Goulart viajara para o Rio ignorando que o país já estava mergulhado na crise que poria fim ao seu governo. Logo cedo, no Palácio Laranjeiras, onde pernoitara, recebeu de seus assessores imediatos as informações de que unidades revoltadas do Exército estavam marchando rumo ao Rio de Janeiro para depô-lo. Alguns desses assessores, sobretudo os mais ferrenhos defensores da situação, ainda tentaram minimizar a rebelião, procurando convencer Goulart de que os militares the eram leais e logo deteriam a facção revoltada. [...] (SKIDMORE, 1988, p. 19).

Mesmo em recuperação, Cony teria a oportunidade de perscrutar, com os próprios olhos, o aludido júbilo dos vitoriosos. Ainda "trôpego e atordoado", o cronista sai às ruas, a confiar "estupidamente no patriotismo e nos sadios princípios que norteiam as nossas gloriosas Forças Armadas", com o objetivo de "ver o povo e a história que ali, em minhas barbas, está sendo feita" (CONY, 2004, p. 11). A partir dali, passa a "compor" imagens também fundamentais, na crônica, ao fortalecimento da articulação "eu/mundo" (ou, de outro modo, à ampliação do "convívio" entre "suas barbas e a história"):

E vejo. Vejo um heróico general, à paisana, comandar alguns rapazes naquilo que mais tarde o repórter da TV-Rio chamou de "gloriosa barricada". Os rapazes arrancam bancos e árvores. Impedem o cruzamento da avenida Atlântica com a rua Joaquim Nabuco. Mas o general destina-se à missão mais importante e gloriosa: apanha dois paralelepípedos e concentra-se na brava façanha de colocar um em cima do outro (CONY, 2004, p. 11).

Destaque-se, por meio de rápida comparação entre as descrições de Skidmore (1988) e as impressões de Cony, o modo como o cronista, ao contrário do historiador, fixa os olhos em detalhes aparentemente banais: em detrimento dos "planos gerais", os quais buscariam "fotografar" a realidade por completo - no caso, o posicionamento das tropas em diversos pontos do Rio de Janeiro e as reações ao evento histórico, conforme a descrição do brasilianista -, privilegiam-se os mínimos fragmentos, simbolizados, na cena, pelos dois paralelepípedos manuseados pelo general em sua "façanha".

Na referida passagem, perceba-se, uma vez mais, a tensão instaurada - no "fato presente", posto que há intervenção direta do cronista na realidade - entre as ações do "eu narrador" e os inusitados acontecimentos cívicos. Importante tratar, ainda, do modo agressivo e irônico como, já na primeira crônica de resistência, o autor se refere aos militares e seu "rosnado" peculiar:

Estou impossibilitado de ajudar os gloriosos herdeiros de Caxias, mas vendo o general em tarefa aparentemente tão insignificante, chego-me a ele e, antes de oferecer meus préstimos patrióticos, pergunto para que servem aqueles paralelepípedos tão sabiamente colocados um sobre o outro.

- General, para que é isto?

O intrépido soldado não se dignou olhar-me. Rosna, modestamente:

Isso é para impedir os tanques do I Exército $\left[{ }^{11}\right]$ !

Apesar de oficial da Reserva - ou talvez por isso mesmo - sempre nutri profunda e inarredável ignorância em assuntos militares. Acreditava, até então, que dificilmente se deteria todo um Exército com dois paralelepípedos ali na esquina da rua onde moro. Não digo nem pergunto mais nada. Retiro-me à minha estúpida ignorância (CONY, 2004, p. 11-12).

Fruto, justamente, do aparente desconhecimento do cronista quanto aos trâmites e às táticas militares assim como à dimensão histórica das primeiras ações do governo autoritário -, revela-se, neste trecho, outra im-

11 O presidente João Goulart dispunha do apoio dos comandantes de tropa do chamado I Exército. A Vila Militar, unidade com maior poder de fogo da América Latina, era comandada por oficiais legalistas e, portanto, fiéis à Constituição e ao governo. 
portante estratégia do autor para intensificação, na narrativa, da articulação "eu/mundo": informações jornalísticas e historiográficas buscam dar suporte às afirmações do "eu narrador", que, confiante - posto que amparado em dados "precisos" -, percebe-se livre para desenvolver as críticas à realidade observada.

Frise-se, contudo, que o uso de tais "informações", como já ressaltado, dá-se de modo distinto ao que pretende Skidmore (1988), Carlos Castello Branco (2007) e outros pesquisadores engajados na descrição historiográfica do período. Para estes, interessará o que Luiz Costa Lima (2006, p. 21) chama de "trajeto peculiar", desde Heródoto, e, sobretudo, de Tucídides: a escrita da história que, por aporia, busca "a verdade do que houve". Em outros termos, trata-se da descrição exclusivamente fundamentada à "prerrogativa" da veracidade dos fatos, sem a qual "ela [a escrita] perde sua função" (LIMA, 2006, p. 21).

Nas crônicas de Cony, para além do mero somatório de fatos, observa-se o desenvolvimento de singular “reinvenção da realidade" (MOISÉS, 1967; SÁ, 1987) - no caso, dos acontecimentos sociopolíticos do Brasil pós-golpe militar -, por meio, principalmente, da articulação "eu/mundo" e, também, da postulação de verdades, segundo conceito de Lima (2006), postas "entre parênteses". Ao contrário da "aporia da verdade", contudo, o uso de informações jornalístico-historiográficas, pelo cronista, permite que se garanta ainda mais autonomia ao "eu narrativo", o qual, em sua "prática textual plurissignificativa” (PEREIRA, 2004), passará a compor complexos "retratos" a partir de fragmentos da realidade vigente.

Em outras palavras, Cony dedica-se, no espaço da crônica, à escrita de sua "história possível", resultante da permanente tensão entre o "eu narrativo" ( 0 mundo de dentro $)$ - a perquirir a realidade - e os acontecimentos macro-históricos (o mundo de fora). Neste sentido, a aproximação entre dados jornalístico-historiográficos e uma série de recursos narrativos e linguísticos - a ironia, a metáfora, a analogia, o humor etc. - fará com que o cronista usufrua de vasta liberdade, a ponto, até mesmo, de se transformar, em meio aos “embates" do Brasil pósgolpe, no que Sá (1987, p. 10) chama de "antena de seu povo".

Desse modo é que, por meio da exploração das potencialidades da língua, torna-se possível ao cronista descortinar, perante seu público, paisagens obscurecidas e/ou completamente ignoradas (SÁ, 1987) por muitos. Em "Da salvação da pátria", o conteúdo jornalístico-historiográfico recolhido pelo autor, desde que articulado às "peripécias do eu", cumpre tal papel de modo efetivo:

Qual não é meu pasmo quando, dali a pouco, em companhia do bardo Carlos Drummond de Andrade, que descera à rua para saber o que se passava, ouço pelo rádio que os dois paralelepípedos do general foram eficazes: o I Exército, em sabendo que havia tão sólida resistência, desistiu do vexame: aderiu aos que se chamavam de rebeldes (CONY, 2004, p. 12).

Observe-se que, no "calor dos acontecimentos", por estar "face a face" com o mundo de fora (no caso, as movimentações do I Exército, então apoiador da legalidade), o cronista parece também se dedicar à "reportagem" da realidade - atividade amparada, contudo, em julgamentos categoricamente particulares. Neste movimento, uma série de expressões adjetivadas ("sólida resistência"; "paralelepípedos [...] eficazes") e de substantivos ("vexame" e "rebeldes") contribuirá para que se dê forma à colagem dos "fragmentos de vida" recolhidos pelo cronista.

Diante de tais fragmentos, contudo, o que mais interessará ao "eu narrativo" será o desafio de interpretar as motivações e/ou reações humanas frente às "tempestades" do tempo histórico. Como exemplo, ressalte-se a máxima do cronista, que, a partir do que observara naquele $1^{\circ}$ de abril de 1964 , quando muitas eram as confusões na avenida Nossa Senhora de Copacabana - onde "ninguém sabe ao certo o que significa 'aderir aos rebeldes" -, definiria: "Não há rebeldes e todos, rebeldes ou não, aderem, que a natural tendência da humana espécie é aderir" (CONY, 2004, p. 12).

Pode-se dizer, pois, que, nas crônicas de $O$ ato e o fato, experiência sensível e informação jornalístico -historiográfica reúnem-se de modo bem articulado, de modo a compor o testemunho do "eu narrativo", que, conforme já se discutiu - a partir de Benjamin (1994) -, está interessado em contar uma "história inteira", mas a partir de fragmentos. Assim é que o narrador, diante da violência institucionalizada (com base numa miríade de antivalores), poderá manter-se justo aos próprios princípios e valores.

\section{Considerações finais}

67 
Das irônicas cenas de "Da salvação da pátria" à tenebrosa "melodia" de "Réquiem para um marechal", as crônicas Cony publicadas no jornal Correio da Manbã - e, posteriormente, reunidas no livro $O$ ato e o fato - estruturam-se no intenso diálogo entre as incongruências da nação sitiada e as íntimas oscilações do já calejado cronista - que, antes tido por alienado, vê-se compelido, por convicções e valores bastante particulares, à desafiadora resistência política.

O adjetivo "calejado", há pouco anteposto ao nome do autor, pretende não apenas frisar sua grande experiência como cronista - amado e odiado, na mesma medida, por milhões de leitores Brasil afora -, mas, principalmente, dizer de sua capacidade, bastante peculiar, de lidar com as possibilidades de diálogo em narrativas curtas.

Romancista premiado, repórter de ofício - em atividade desde a década de 1940, como aqui se discutiu -, o autor compreende muito bem o permanente "jogo" entre jornalismo e literatura em meio ao complexo espaço simbólico do jornal. Trata-se, enfim, do atabalhoado "ambiente" onde informação e imaginação relacionamse de modo intenso - apesar de nem sempre amistoso.

Pois neste território de múltipla agitação, Cony não se furta às responsabilidades do exercício da opinião. Ao contrário, diverte-se com a possibilidade de dizer o que pensa acerca do tempo, da vida, dos homens e suas mediocridades. Distrai-se, até mesmo, a ponto de parecer "kamikaze" em episódios nos quais o silêncio - para muitos - seria a melhor maneira de proteger a própria integridade intelectual.

Nas crônicas de Cony, o que se percebe é, justamente, a louvação ao diálogo, por meio de estratégias detalhadamente tramadas. Trata-se de ininterruptos "convites" para que, a seu modo, o leitor participe de tudo o que se pretende reinventar no território da crônica, ambiente - a um só tempo - de realidade e epifania.

Exatamente a partir de tal dialogismo é que, em 1964, o autor busca estimular a mobilização, denunciar barbáries e, ainda, reconstruir as bases de nosso imaginário acerca daquele triste País sitiado. Daí a motivação para que, já nos primeiros movimentos da "quartelada de $1^{\circ}$ de abril" - alcunha obsessivamente repetida em $O$ ato e o fato -, os olhos do autor passassem a perquirir paradoxos e mentiras.

Não interessava ao cronista, afinal, o que, nos jornais, nas ruas, nos debates despretensiosos, revelavase definitivo, absoluto, consensual. Ao contrário, as retinas de Cony - como escritor do dissenso - ansiavam por captar as mais cruas "verdades" do Brasil dos desiguais, dos desvalidos, sedentos e encarcerados. Pátria, enfim, do desprezo pela condição humana.

De todo modo, é bem verdade, Pátria esta a ser reinventada, narrativamente, pelo mesmo irado cronismo capaz de redesenhar - com o auxílio de impropérios, analogias e metáforas escatológicas - o perfil dos poderosos militares do Alto Comando, transformados por Cony, dia a dia, em horripilantes "criaturas" do mais temível fabulário infantil.

No espaço plurissignificativo da crônica - onde realidade e ficção frequentam-se animadamente -, o autor transforma seu engajamento sociopolítico em discurso polissêmico, como resultado da rica soma entre o registro jornalístico-historiográfico dos acontecimentos e a imaginação crítica do "eu narrativo", o que resultará em "retratos" caleidoscópicos - posto que fragmentados - da realidade brasileira.

Escritor experiente, atento às possibilidades da Indústria Cultural, Cony sabe disseminar tais petardos verbais com a vitalidade de quem, nos tatames, distribui socos e pontapés. Para tal, lança mão de articuladas estratégias narrativas, com o objetivo de não apenas atrair a atenção de seus leitores - entre os quais, os próprios militares -, mas, principalmente, de instigá-los, no ambiente estético, à reflexão ética.

Desde os passos iniciais da "revolução que retrocede", Cony não aceitaria as condições, imposições e propostas sociopolíticas dos vencedores. Daí a necessidade de "reinvenção do real"; daí a recorrência à prática textual plurissignificativa responsável, por meio de colagens várias, pela denúncia dos trambiques, absurdos e indecências do poder. Daí, pois, a composição dos inflamados discursos de "protesto", nos quais informação e ficção, intimidade e história, jornalismo e literatura parecem notas de uma mesma sinfonia.

Do ponto de vista temático, da mesma maneira como, até 1964, as intempéries do tempo servem ao romancista de argumento para sua obra ficcional - caracterizada pela frequente abordagem de questões como a desagregação dos indivíduos, o colapso da família, as ruínas sociais e os vazios da existência (HOHLFELDT, 2001) -, também a crônica torna-se palco para exibição dos muitos escombros e fraturas da sociedade brasileira.

Diante da nação sitiada, afinal, que alternativa restaria ao cronista, senão o investimento em profícuos diálogos com o leitor, por meio dos quais torna-se possível, ao mesmo tempo, estimular a reflexão em torno dos atos e fatos da nação; denunciar abusos do poder hegemônico; lutar pela dignidade da condição humana ou, simplesmente, dividir com outrem o (enorme) peso 
do despotismo institucionalizado?

Para cumprir com tais demandas, no que se refere às práticas textuais empregadas por Cony, destaque-se, em primeiro lugar, o fortalecimento da autonomia do "eu narrativo", responsável por descrever o País de modo muito particular - a partir, principalmente, de informações jornalístico-historiográficas - e, ainda, por permitir que os acontecimentos históricos fossem delicadamente articulados à experiência sensível do cronista.

Ressalte-se, também, a estratégia narrativa da conclamação à luta, por meio da qual o autor consolida, de modo efetivo, o status de cumplicidade com seus leitores. Como resultado de tal iniciativa, lembremo-nos das inúmeras cartas recebidas por Cony, no Correio da Manhã, ao longo dos meses de abril e junho de 1964, com importantes denúncias - muitas das quais, transformadas em crônicas - acerca das atrocidades do regime.

Há que se enfatizar, por fim, a importância das narrativas de $O$ ato e o fato - na totalidade da obra literária e jornalística de Carlos Heitor Cony - como exemplos contundentes da acurada e intensa reflexão do autor em torno da temática tida, por ele próprio, como a primeira e única razão de sua escrita: o homem e suas vicissitudes. Em linhas gerais, eis a temática a que o escritor se dedica, reflexiva e permanentemente, não só nas crônicas de resistência, mas também nos romances, nos contos e nas adaptações. Em outros termos, fazer literatura significaria, para Cony, a possibilidade de perscrutar os desejos nem sempre dignos e altruístas - da humanidade.

\section{Referências}

ALVES, Hermano. Orelha. In: CONY, Carlos Heitor. O ato e o fato - Crônicas políticas. Rio de Janeiro: Civilização Brasileira, 1964.

BARTHES, Roland [et. al.]. Análise estrutural da narrativa. Petrópolis (RJ): Vozes, 2008.

BOSI, Alfredo (Org.). Cultura brasileira - Temas e situações. São Paulo: Ática, 2006.

BRANCO, Carlos Castello. Os militares no poder - de 1964 ao AI-5. $2^{\text {a }}$ ed. Rio de Janeiro: Nova Fronteira, 2007.

CARVALHO, José Murilo de. Cidadania no Brasil: o longo caminho. Rio de Janeiro: Civilização Brasileira, 2003.

CASTRO, Ruy. O leitor apaixonado - Prazeres à luz do abajur. Org. Heloisa Seixas. São Paulo: Cia. das Letras, 2009.

CONY, Carlos Heitor. Da arte de falar mal. Rio de Janei- ro: Civilização Brasileira, 1963.

O ato e o fato - Crônicas políticas. Rio de Janeiro: Civilização Brasileira, 1964.

Prefácio do autor. In: CONY, Carlos Heitor. O ato e o fato - Crônicas políticas. Rio de Janeiro: Civilização Brasileira, 1964.

A crônica como gênero do jor-

nalismo e da literatura. Folha de S. Paulo, São Paulo, 16 out. 1998. Ilustrada, p. E14.

CONY, Carlos Heitor. A crônica como gênero do jornalismo e da literatura. Folha de S. Paulo, São Paulo, 6 dez. 2002. Ilustrada, p. E16.

. O ato e o fato - O som e a fúria das crônicas contra o golpe de 1964. Rio de Janeiro: Objetiva, 2004.

A revolução dos caranguejos. São

Paulo: Cia. das Letras, 2004.

20 set. 2007. Entrevista concedida via e-mail a Maurício Guilherme Silva Jr.

Crônicas, colunas e mosquitos.

Folha de S. Paulo, São Paulo, 25 abr. 2008. Ilustrada, p. E16.

Rio de Janeiro (RJ), Brasil, 08 mai. 2008. Entrevista concedida a Maurício Guilherme Silva Jr.

O legado de nossa miséria. Folha

de S. Paulo, São Paulo, 28 mar. 2008. Ilustrada, p. E13.

. Conselho ocioso aos tiranos. Fo-

tha de S. Paulo, São Paulo, 05 dez. 2008. Ilustrada, p. E13.

. AI-5 - A geração do deserto. Fo-

tha de S. Paulo, São Paulo, 12 dez. 2008. Ilustrada, p. E15.

. Duas ou três coisas sobre o AI-

5. Folha de S. Paulo, São Paulo, 19 dez. 2008. Ilustrada, p. E15.

A lata de lixo da história. Folha de

S. Paulo, São Paulo, 15 jan. 2010. Ilustrada, p. E14.

Cena doméstica dos anos 60 .
69 
Folha de S. Paulo, São Paulo, 4 fev. 2011. Ilustrada, p. E12. O veneno da ditadura. Folha de

S. Paulo, São Paulo, 30 set. 2011. Ilustrada, p. E14.

CUNHA, Newton. Orelha. VALCÁRCEL, Amelia. Ética contra estética. Trad. e notas adicionais de Newton Cunha. São Paulo: Perspectiva, SESC, 2005.

HOHLFELDT, Antonio. O caso Cony. In: Cadernos de Literatura. São Paulo: Instituto Moreira Salles, no12 Carlos Heitor Cony, p. 88-113, dez. 2001.

LIMA, Luiz Costa. História. Ficção. Literatura. São Paulo: Cia. das Letras, 2006.

MANCHETE. Rio de Janeiro, abr. 1994. Ano 11. Edição histórica, p. 4.

MOISÉS, M; PAES; J. P. (Org.). Pequeno dicionário de Literatura Brasileira. $5^{a}$ ed. São Paulo: Cultrix, 1999.

PEREIRA, Wellington. Crônica - A arte do fútil do útil e do fútil. Salvador: Calandra, 2004.

PINTO, Lúcio Flávio. Cony, o herói que não foi. Observatório da Imprensa. 28. dez. 2010. Disponível em: <www. observatoriodaimprensa.com.br/news/view/cony-o -heroi-que-nao-foi>. Acesso em 23 fev. 2011.

REIS, D. A.; RIDENTI, M.; MOTTA, R. P. S. (Org.). $O$ golpe e a ditadura militar - 40 anos depois (1964-2004). Bauru (SP): Edusc: 2004.

SÁ, Jorge de. A crônica. $3^{a}$ ed. Série "Princípios". São Paulo: Ática, 1987.

SANDRONI, Cícero. Quase Cony - Perfis do Rio. Rio de Janeiro: Relume Dumará, 2003.

SELIGMANN-SILVA, Márcio (Org.). História, memória, literatura - $\mathrm{O}$ testemunho na era das catástrofes. Campinas (SP): Editora da Unicamp, 2003.

SILVEIRA, Ênio. A farsa de abril ou o mito da honradez cívica (Prefácio). In: CONY, Carlos Heitor. O ato e o fato - Crônicas políticas. Rio de Janeiro: Civilização Brasileira, 1964.

SKIDMORE, Thomaz E. Brasil - De Castelo a Tancredo. $8^{a}$ ed. Rio de Janeiro: Paz e Terra, 1988.
VERISSIMO, Luis Fernando. A última ironia. In: CONY, Carlos Heitor. O ato e o fato - O som e a fúria das crônicas contra do Golpe de 1964. Rio de Janeiro: Objetiva, 2004. 